\title{
Residue analysis of penicillines in livestock and marine products
}

\author{
Ji Young Song, Soo Jung Hu, Hyunjin Joo, Mi Ok Kim, Joung Boon Hwang, Yoon Jung Han, \\ Yujihn Kwon, Shin Jung Kang and Dae Hyun Cho ${ }^{\star}$ \\ Hazardous Substances Analysis Division, Gyeoin Regional Food and Drug Administration \\ \#217 Juanyeok-Gil, Nam-Gu, Incheon 402-835, Korea
}

(Received January 12, 2012; Revised August 8, 2012; Accepted August 9, 2012)

\section{국내 유통 축·수산물 중 페니실린계 동물용의약품에 \\ 대한 잔류실태조사}

\author{
송지영 · 허수정 · 주현진 · 김미옥 · 황정분 · 한윤정 · 권유진 · 강신정 · 조대현 \\ 경인지방식품의약품안전청 유해물질분석과 \\ (2012. 1. 12. 접수, 2012. 8. 8. 수정, 2012. 8. 9. 승인)
}

\begin{abstract}
Penicillins belong to the $\beta$-lactam class of antibiotics, and are frequently used in human and veterinary medicine. Despite the positive effects of these drugs, improper use of penicillins poses a potential health risk to consumers. This study has been undertaken to determinate multi-residues of penicillins, including amoxicillin, ampicillin, oxacillin, bezylpenicillin, cloxacillin, dicloxacillin, and nafcillin, using liquid chromatographic tandem mass spectrometer (LC-MS/MS). The developed method was validated for specificity, precision, recovery, and linearity in livestock and marine products. The analytes were extracted with $80 \%$ acetonitrile and clean-up by a single reversed-phase solid-phase extraction step. Six penicillins presented recoveries higher than $76 \%$ with the exception of Amoxicillin. Relative standard deviations (RSDs) were not more than $10 \%$. The method was applied to 225 real samples. Benzylpenicillin was detected in 12 livestock products and 7 marine products. Amoxicillin, ampicillin, cloxacilllin, dicloxacillin, nafcillin and oxacillin were not detected. The detected levels were $0.001 \sim 0.009 \mathrm{mg} / \mathrm{kg}$ in livestock products excluding eggs and milk. In marine products, the detected levels were under $0.03 \mathrm{mg} / \mathrm{kg}$. They were under the MRL levels. As monitoring results, it is identified to be safe but it is considered that safety management of antibiotics should continue by monitoring.

요 약: 페니실린계 항생물질은 $\beta$-lactam 계열의 항생물질로서 인간과 동물에게 널리 사용되어지는 항생 물질이다. 이러한 항생항균물질들의 오남용은 소비자가 항생제에 노출될 위험성을 증가시킨다. 본 연구 에서는 국내 유통 중인 축 - 수산물을 대상으로 LC-MS/MS를 이용하여 페니실린계 동물용의약품 7종인 아목시실린, 암피실린, 벤질페니실린, 클록사실린, 디클록사실린, 나프실린, 옥사실린에 대한 잔류량을 조 사하였다. 특이성, 정밀성, 회수율, 직선성을 통해 시험법의 유효성을 확인하였으며 아목시실린을 제외한 나머지 6종은 모두 $76 \%$ 이상의 회수율을 보였고, $\mathrm{RSD}$ 는 $10 \%$ 이하로 나타내었다. 시료는 $80 \%$ 아세토
\end{abstract}

$\star$ Corresponding author

Phone : +82-(0)32-450-3251 Fax : +82-(0)32-429-3388

E-mail : dhcho5@korea.kr 
니트릴로 추출한 후 고체상 추출 카트리지를 사용하여 정제 한 후 분석하였다. 축 - 수산물 225건을 대 상으로 잔류량을 조사한 결과 벤질페니실린이 축산물에서 12건, 수산물에서 7건으로 총 19건이 검출되 었고 나머지 6개 항목인 아목시실린, 암피실린, 클록사실린, 디클록사실린, 나프실린, 옥사실린은 검출되 지 않았다. 벤질페니실린이 검출된 축산물은 우유와 알을 제외한 소고기, 돼지고기, 닭고기이었으며 검 출 수준은 0.001 0.009 mg/kg으로 잔류허용기준(MRL)인 $0.05 \mathrm{mg} / \mathrm{kg}$ 이하로 검출되었다. 수산물에서 검 출된 7건은 잔류허용기준인 $0.03 \mathrm{mg} / \mathrm{kg}$ 이하로 검출되었다. 본 연구사업에서 수행한 모니터링 결과 해 당항목의 경우 대부분 기준치 이하로 검출되어 비교적 안전한 수준인 것으로 나타났으나, 향후 지속적인 잔류실태조사와 제도적인 관리지도를 통하여 동물용의약품의 오남용에 대한 안전관리가 이루어져야 할 것으로 사료된다.

Key words: livestock product, marine product, LC-MS/MS, monitoring, penicillins

\section{1. 서 론}

우리나라 축수산업의 항생제 사용량은 선진국들에 비해 년간 축산물생산량 대비 항생제 사용량이 높은 수준이다. ${ }^{1}$ 항생제 사용량을 축종별로 살펴보면 돼지 가 가장 많이 사용되었고 그 다음으로는 닭, 수산물, 소 순으로 나타났으며, 용도별로는 배합사료 제조용이 약 $54 \%$ 로 가장 많이 사용되었으며 다음으로는 자가 치료용, 수의사 처방용 순으로 나타났다. ${ }^{2}$ 항생제의 과 다 사용 문제는 궁극적으로 항생제의 식품 내 잔류 문제를 유발한다. 축수산물에 항생제를 투여하였을 경 우 휴약 기간이 경과한 후에 출하 - 도축해야 하며 이 를 준수하지 않을 경우 항생제가 잔류하게 되는데 식 품 내 잔류된 항생제는 비록 극소량이라고 하더라도 사람이 섭취하였을 경우, 인체 내성률 증가로 이어져 사람의 질병 치료를 어렵게 만들 수 있다. ${ }^{3-11}$ 따라서 미국, 유럽연합(EU)을 비롯한 세계 주요 국가는 물론 국제식품규격위원회(CODEX) 등에서 최대잔류허용기 준치(MRL, maximum residue level)를 설정하여 규제 하고 있으며, 국내에서는 현재(2011년 12월) 146종의 동물용의약품에 대한 잔류허용기준을 설정하여 관리 하고 있다. ${ }^{12}$ 우리나라에서는 동물용의약품 중 가장 많이 사용하는 것이 항생제 및 합성항균제이며 테트 라싸이클린계, 페니실린계, 설폰아마이드계, 아미노글 리코사이드계, 마크로라이드계, 퀴놀린계 순으로 사용

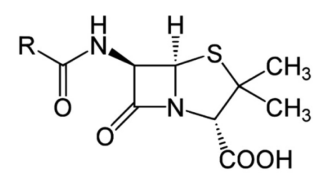

Fig. 1. Penicillin core structure.
량이 많은 것으로 조사되고 있다. 또한, 주로 검출되는 동물용의약품은 테트라싸이클린계, 페니실린계, 퀴놀린 계 및 설폰아마이드계 인 것으로 보고된 바 있다. ${ }^{13,14}$ 축수산업에서 많이 사용되고 있는 페니실린계 항생제 는 $\beta$-lactam 구조를 기본구조(Fig. 1)로 가지고 있는 가장 널리 사용되는 항생제 중의 하나이다. 페니실린 은 곰팡이에 의해 발효 과정에서 생성되는 생합성 페 니실린과 모든 페니실린에서 발견되는 6-아미노페니 실린산의 화학구조를 변화시켜 얻을 수 있는 반합성 페니실린으로 분류된다. 페니실린의 구조가 변화함에 따라 항생제의 성질도 달라지므로 여러 형태의 페니 실린이 치료 목적에 따라 다르게 생산되고 있다. 페니 실린은 세균 세포막인 펩티도글리칸의 교차연결 배열 을 파괴하여 항균작용을 나타내는데, 페니실린의 베타 -락탐의 일부분이 펩티도글리칸 분자를 연결하는 트랜 스펩니다아제와 임의로 결합하여 세균의 세포벽을 약 화시키고, 이렇게 세포벽이 약화된 세포는 삼투압 변화 를 이기지 못하고 세포벽이 터져 세균이 죽게 된다. ${ }^{15}$ 페니실린계 항생제의 경우, 인체 치료용으로 널리 사 용되고 있으며 임상환자 뿐만 아니라 일반인들에게 있어서도 높은 내성률이 나타나고 있다는 점을 고려 한다면 축수산업에서의 페니실린 사용은 엄격히 규제 되어야 할 것이다.

본 연구에서는 부적합이력 및 사용량이 많은 동물 용의약품 중 페니실린계 항생제인 아목시실린, 암피실 린, 벤질페니실린, 클록사실린, 디클록사실린, 나프실 린, 옥사실린 등 페니실린계 7종(Fig. 2)에 대하여 2010년 식품의약품안전평가원 화학물질과에서 새롭게 확립한 페니실린계 7종에 대한 동시다성분 분석법 ${ }^{16}$ 을 이용하여 국내 유통 중인 축수산물을 대상으로 실태 조사를 수행하였다. 


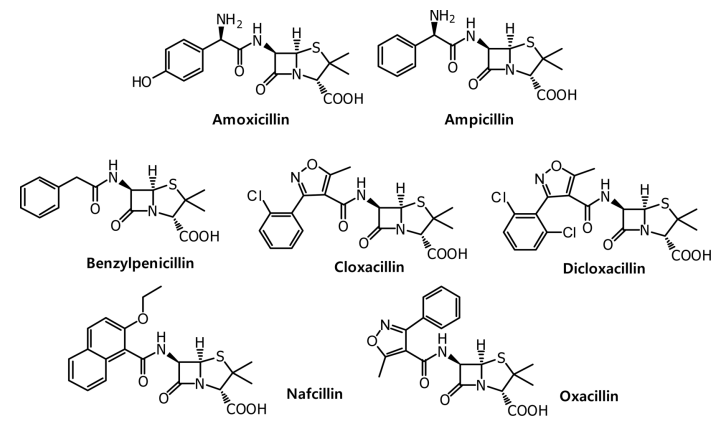

Fig. 2. Molecular structures of Penicillins.

\section{2. 재료 및 방법}

\section{1. 실험재료}

본 연구에 사용한 시료는 서울, 인천, 대전, 대구, 부산, 울산, 광주의 7개 지역 대형할인점에서 유통되 고 있는 축.수산물로서 총 225건이었다. 식품군은 소 고기(27건), 돼지고기(24건), 닭고기(27건), 계란(28건), 우유(29건), 넙치(19건), 조피볼락(21건), 장어(24건), 새우(26건)로 총 9종이었다. 대상 식품은 식품공전에 기준이 설정되어있는 식품 중에 국민영양조사의 1 일 식품섭취량을 참고로 하여 섭취량이 많은 식품위주로 선정하였다. 지역별 검체 수집건수는 각 집단의 크기 에 비례해서 표본을 추출하는 방법인 인구확률비례추 출법을 이용하여 결정하였다. 검체는 구매 즉시 $4{ }^{\circ} \mathrm{C}$ 에서 냉장 보관하면서 유통기한 이내에 분석을 하였 으며 장기간 보관하여야 하는 경우 냉동 보관하여 사 용하였다.

\section{2. 표준품 및 시약}

표준품인 아목시실린, 암피실린, 클록사실린, 디클 록사실린, 옥사실린은 Sigma-Aldrich에서, 벤질페니실 린은 Wako Pure Chemical Industries Inc. (Osaka, Japan), 나프실린은 Dr. Ehrenstrofer GmbH (Augsburg, Germany) 에서 구입하였다. 제이인산나트륨(disodium hydrogen phosphate), 인산이수소칼륨(potassium dihydrogen phosphate), 삼염화초산(tricloroacietic acid) 개미산 (formic acid)은 Sigma-Aldrich (St.Louis, MO. USA)에 서 구매하였다. 그 외 분석용 시약 및 용매는 Wako Pure Chemical Industries Inc. (Osaka, Japan), (St.Louis, MO, USA), Merck Inc. (Darmstasdt, Germany), J.T.Baker (Phillipsburg, USA), Burdick \& Jackson (Muskegon, Mi, USA)에서 HPLC급을 구매하였다. 또한 정제과정에 사용된 고체상 추출 카트리지(solid-phase extraction cartridge)는 HLB 카트리지(500 mg, $6 \mathrm{~mL}$, Waters)를 사용하였다.

\section{3. 표준용액의 제조}

아목시실린, 암피실린, 벤질페니실린, 클록사실린, 디 클록사실린, 나프실린 및 옥사실린은 표준품을 정밀히 달아 증류수에 용해시켜 각각 $100 \mathrm{mg} / \mathrm{L}$ 농도가 되도록 한 후 이를 혼합하여 $0.00098,0.00195,0.0039,0.0078$, $0.0156,0.0313,0.0625$ 및 $0.125 \mathrm{mg} / \mathrm{L}$ 의 농도가 되도록 희석하여 사용하였다. 표준원액은 $-20{ }^{\circ} \mathrm{C}$ 에서 냉동 보 관하여 실험 전에 희석하여 표준용액으로 사용하였다.

\section{4. 사용기기 및 분석조건}

시료 전처리를 위해서, 원심분리기(Beckman, Japan), Vacuum manifolder (Waters, USA), 회전감압농축기 (EYELA, Japan)와 질소농축기(TAITEC, Japan)를 사 용하였다. 고속액체크로마토그래프(High Performance Liquid Chromatograph, HPLC)는 Agilent Technologies 1200 series(Agilent, Germany)를 사용하였으며, 질량분 석기(tandem mass spectometer)는 ABI 4000 LC-MS/ MS System(AB, USA)을 사용하였다. 페니실린계 동 물용의약품 분석법은LC-MS/MS를 사용하였으며 분석 조건은 Table 1 과 같다.

\section{5. 전처리}

균질화한 시료(소고기, 닭고기, 넙치) $2 \mathrm{~g}$ 을 정밀히 달아 균질기 용기에 넣고 아세토니트릴/물(8:2) 10 $\mathrm{mL}$ 를 넣고 2 분간 균질화 시켰다. 아세토니트릴/물 (8:2) $10 \mathrm{~mL}$ 로 잔사 및 용기를 씻어 내려 상기 액과 합한다. 유는 $20 \mathrm{~mL}$ 을, 알은 $5 \mathrm{~g}$ 을 $50 \mathrm{~mL}$ 원심분리 관에 취하여 유는 아세토니트릴 $50 \mathrm{~mL}$, 알은 $20 \mathrm{~mL}$ 을 넣고 $20 \%$ 트리클로로초산 $0.5 \mathrm{~mL}$ 을 넣어 10 분간 진탕 혼합하였다. 균질화한 시료를 $5,000 \mathrm{G}$ (유와 알은 $9,000 \mathrm{G}), 4{ }^{\circ} \mathrm{C}$ 에서 10 분간 원심분리 하여 상층액을 감압농축플라스크에 넣은 후 $50{ }^{\circ} \mathrm{C}$ 이하의 수욕 상에 서 감압농축 하였다. 잔액을 $4 \mathrm{~mL}$ 정도 남기고 이를 $50 \mathrm{~mL}$ 원심분리관에 옮기고 아세토니트릴/물(5:5) 6 $\mathrm{mL}$ 으로 농축플라스크를 세척하면서 농축액과 합하였 다. 헥산 $10 \mathrm{~mL}$ 을 넣고 5 분간 균질화한 후 $5,000 \mathrm{G}$ (유와 알은 $9,000 \mathrm{G}), 4{ }^{\circ} \mathrm{C}$ 에서 10 분간 원심분리를 하 여 헥산층을 버리고 이 과정을 한번 더 반복하였다. 추출액을 감압농축플라스크에 옮기고 $50{ }^{\circ} \mathrm{C}$ 이하의 수욕상에서 감압농축한 후 잔액을 $2.5 \mathrm{~mL}$ 정도를 남 겨 $2.5 \mathrm{~mL} \mathrm{0.1} \mathrm{M} \mathrm{Na} 2 \mathrm{HPO}_{4}$ 용액에 용해시켰다(유와 
Table 1. LC-MS/MS parameter for the analysis of penicillins

\begin{tabular}{|c|c|c|c|c|}
\hline Parameter & \multicolumn{4}{|c|}{ Conditions } \\
\hline 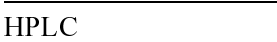 & \multicolumn{4}{|c|}{ Agilent Technologies 1200 series } \\
\hline Column & \multicolumn{4}{|c|}{ Capcell pak UG C18 $(2.0 \mathrm{~mm} \mathrm{ID} \times 150 \mathrm{~mm}, 5 \mu \mathrm{m})$} \\
\hline \multirow[t]{8}{*}{ Mobile Phase } & \multicolumn{4}{|c|}{$\begin{array}{l}\text { Solvent A : } 10 \mathrm{mM} \text { Ammonium formate }(0.1 \% \text { formic acid }) \\
\text { Solvent B : } \mathrm{MeOH}\end{array}$} \\
\hline & \multicolumn{3}{|c|}{ Time $(\min ) \quad$ A $(\%) \quad$ B $(\%)$} & \\
\hline & 0.0 & 80 & $\begin{array}{l}\text { B }(\%) \\
20\end{array}$ & \\
\hline & 2.0 & 80 & 20 & \\
\hline & 2.1 & 0 & 100 & \\
\hline & 12.0 & 0 & 100 & \\
\hline & 12.5 & 80 & 20 & \\
\hline & 15.0 & 80 & 20 & \\
\hline Flow rate & \multicolumn{4}{|l|}{$300 \mu \mathrm{L} / \mathrm{min}$} \\
\hline Injection vol. & \multicolumn{4}{|l|}{$10 \mu \mathrm{L}$} \\
\hline Mass Spectrometry & \multicolumn{4}{|c|}{ API 4000 LC-MS/MS System, AB } \\
\hline Ion mode & \multicolumn{4}{|c|}{ ESI (positive) } \\
\hline Spray Voltage & \multicolumn{4}{|l|}{$5.5 \mathrm{kV}$} \\
\hline Sheath Gas & \multicolumn{4}{|l|}{$\mathrm{N}_{2}(50 \mathrm{psi})$} \\
\hline Capillary Temperature & \multicolumn{4}{|l|}{$500{ }^{\circ} \mathrm{C}$} \\
\hline Auxiliary Gas & \multicolumn{4}{|l|}{$\mathrm{N}_{2}(50 \mathrm{psi})$} \\
\hline Collision Gas & \multicolumn{4}{|l|}{$\mathrm{N}_{2}$} \\
\hline Collision Voltage & \multicolumn{4}{|c|}{$\begin{array}{l}\text { Amoxiciliin(25), Ampicillin(25), Benzylpenicillin(15) } \\
\text { Cloxacillin(19), Dicloxacillin(19), Nafcillin(19), Oxacillin(17) }\end{array}$} \\
\hline \multirow[t]{3}{*}{ Scan type } & \multicolumn{4}{|c|}{ MRM (Multiple Reaction Monitoring) } \\
\hline & & Compound & Precursor ion $(\mathrm{m} / \mathrm{z})$ & Product ions $(\mathrm{m} / \mathrm{z})$ \\
\hline & & $\begin{array}{l}\text { Amoxiciliin } \\
\text { Ampicillin } \\
\text { Benzylpenicillin } \\
\text { Cloxacillin } \\
\text { Dicloxacillin } \\
\text { Nafcillin } \\
\text { Dxacillin }\end{array}$ & $\begin{array}{l}366 \\
350 \\
335 \\
436 \\
470 \\
415 \\
402\end{array}$ & $\begin{array}{l}\frac{349}{106}, 114 \\
\frac{160}{\frac{160}{277}}, 176 \\
\frac{160}{311}, \frac{160}{256} \\
\frac{199}{160}, 243\end{array}$ \\
\hline
\end{tabular}

알은 $0.1 \mathrm{M} \mathrm{NaOH}$ 를 이용하여 $\mathrm{pH}$ 9로 맞춘다). 미리 $5 \mathrm{~mL}$ 메탄올과 $5 \mathrm{~mL}$ 물, $5 \mathrm{~mL} 0.05 \mathrm{M} \mathrm{Na}_{2} \mathrm{HPO}_{4}$ 용 액으로 활성화를 시킨 HLB 카트리지에 시료추출액을 흡착시키고, $5 \mathrm{~mL} 0.05 \mathrm{M} \mathrm{Na}_{2} \mathrm{HPO}_{4}$ 용액으로 세척하 고 건조시킨 후 $0.05 \mathrm{M} \mathrm{KH}_{2} \mathrm{PO}_{4} /$ 아세토니트릴(50/50, v/ v) $5 \mathrm{~mL}$ 로 용출시켰다. 이 용출액을 $50{ }^{\circ} \mathrm{C}$ 이하의 수 욕 상에서 아세토니트릴을 질소 농축한 다음 잔류물을 물로 용해하여 최종부피를 $5 \mathrm{~mL}$ 가 되도록 하여 0.2 $\mu \mathrm{m}$ 필터로 여과한 후 시험용액으로 하였다(Fig. 3).

\section{6. 실험법 검증}

회수율 시험은 표준용액을 시료에 최대잔류허용기 준(MRL) 농도가 되도록 첨가하여 전처리 과정을 거
쳐 분석하였으며 3 번 반복 시험하여 회수율을 산출하 였다. 직선성은 아목시실린, 암피실린, 벤질페니실린, 클록사실린, 디클록사실린, 나프실린, 옥사실린 표준용 액을 $0,0.00098,0.00195,0.0039,0.0078,0.0156,0.0313$, 0.0625 및 $0.1250 \mathrm{mg} / \mathrm{L}$ 의 8 개의 농도에 대하여 검량 선(calibration curve)를 작성하여 평가하였다. 또한 검 출한계 및 정량한계는 $\mathrm{ACS}^{17}$ 의 방법에 따라 아래의 식으로 구하였다.

Limit of detection (LOD) $=\mathrm{As}-\mathrm{Ab} \geq 3 \times \mathrm{Sb}$

Limit of quntification (LOQ) $=\mathrm{As}-\mathrm{Ab} \geq 10 \times \mathrm{Sb}$

As: the mean of area of sample signal

$\mathrm{Ab}$ : the mean of area of blank signal

Sb: standard deviation 


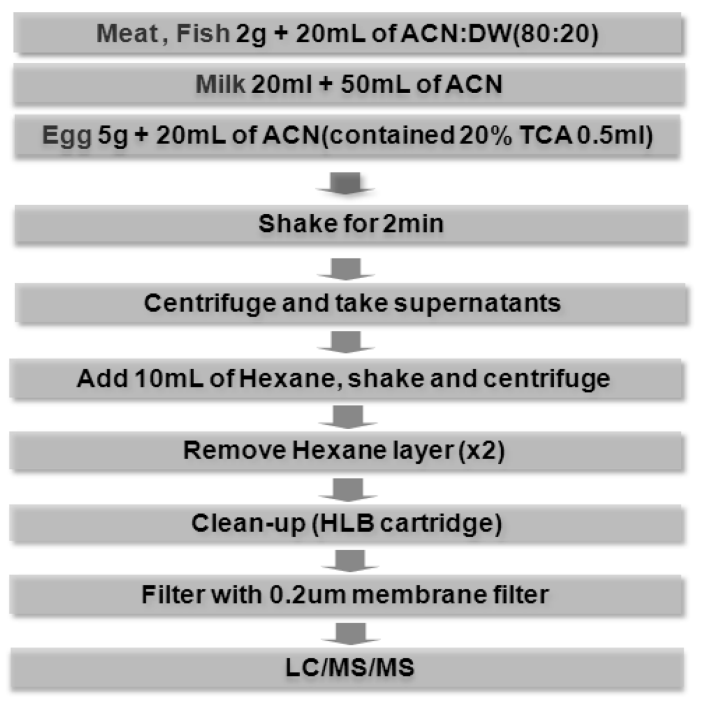

Fig. 3. Analytical method for penicillins residues.

\section{3. 결과 및 고찰}

\section{1. 직선성, 검출 및 정량한계, 회수율}

아목시실린, 암피실린, 벤질페니실린, 클록사실린, 디클록사실린, 나프실린, 옥사실린 표준용액은 0 , $0.00098,0.00195,0.0039,0.0078,0.0156,0.0313$, 0.0625 및 $0.1250 \mathrm{mg} / \mathrm{L}$ 의 8 개의농도에 대하여 검량선

Table 2. LOD and LOQ for detection penicillins in beef

\begin{tabular}{lcccc}
\hline \hline \multicolumn{1}{c}{ Compounds } & $\begin{array}{c}\mathrm{LOD} \\
(\mathrm{mg} / \mathrm{kg})\end{array}$ & $\begin{array}{c}\mathrm{LOQ} \\
(\mathrm{mg} / \mathrm{kg})\end{array}$ & $\mathrm{R}^{2}$ & $\begin{array}{c}\mathrm{CV} \\
(\%)\end{array}$ \\
\hline Amoxicillin & 0.0015 & 0.005 & 0.9998 & 9.2 \\
Ampicillin & 0.0015 & 0.005 & 0.9999 & 2.9 \\
Benzylpenicillin & 0.0003 & 0.001 & 0.9997 & 6.4 \\
Cloxacillin & 0.0015 & 0.005 & 0.9999 & 6.4 \\
Dicloxacillin & 0.0003 & 0.001 & 0.9997 & 5.5 \\
Nafcillin & 0.0003 & 0.001 & 0.9978 & 5.9 \\
Oxacillin & 0.0003 & 0.001 & 0.9998 & 7.1 \\
\hline
\end{tabular}

Table 3. LOD and LOQ for detection penicillins in chicken

\begin{tabular}{lcccc}
\hline \hline \multicolumn{1}{c}{ Compounds } & $\begin{array}{c}\mathrm{LOD} \\
(\mathrm{mg} / \mathrm{kg})\end{array}$ & $\begin{array}{c}\mathrm{LOQ} \\
(\mathrm{mg} / \mathrm{kg})\end{array}$ & $\mathrm{R}^{2}$ & $\begin{array}{c}\mathrm{CV} \\
(\%)\end{array}$ \\
\hline Amoxicillin & 0.0015 & 0.005 & 0.9998 & 1.5 \\
Ampicillin & 0.0015 & 0.005 & 0.9998 & 1.3 \\
Benzylpenicillin & 0.0003 & 0.001 & 0.9997 & 2.7 \\
Cloxacillin & 0.0015 & 0.005 & 0.9998 & 2.6 \\
Dicloxacillin & 0.0003 & 0.001 & 0.9998 & 3.1 \\
Nafcillin & 0.0003 & 0.001 & 0.9970 & 3.4 \\
Oxacillin & 0.0003 & 0.001 & 0.9999 & 3.5 \\
\hline
\end{tabular}

Table 4. LOD and LOQ for detection penicillins in fish

\begin{tabular}{lcccc}
\hline \multicolumn{1}{c}{ Compounds } & $\begin{array}{c}\text { LOD } \\
(\mathrm{mg} / \mathrm{kg})\end{array}$ & $\begin{array}{c}\mathrm{LOQ} \\
(\mathrm{mg} / \mathrm{kg})\end{array}$ & $\mathrm{R}^{2}$ & $\begin{array}{c}\mathrm{CV} \\
(\%)\end{array}$ \\
\hline Amoxicillin & 0.0015 & 0.005 & 0.9993 & 2.6 \\
Ampicillin & 0.0003 & 0.001 & 0.9999 & 5.4 \\
Benzylpenicillin & 0.0003 & 0.001 & 0.9999 & 5.3 \\
Cloxacillin & 0.0015 & 0.005 & 0.9997 & 4.0 \\
Dicloxacillin & 0.0015 & 0.005 & 0.9995 & 1.7 \\
Nafcillin & 0.0015 & 0.005 & 0.9993 & 2.4 \\
Oxacillin & 0.0015 & 0.005 & 0.9995 & 3.9 \\
\hline
\end{tabular}

(calibration curve)를 작성한 결과 상관계수가 0.99 이 상으로 CODEX에서 요구하는 0.95 이상이었다. 또한 검출한계 및 정량한계는 $\mathrm{ACS}^{17}$ 의 방법에 따라 계산하 였으며, 그 결과는 Table 2-4과 같았다. 회수율은 분석 시료에 최대잔류허용기준(MRL) 농도가 되도록 첨가 하여 전처리 과정을 거쳐 분석하였으며 3번 반복 실 험하여 회수율을 산출하였다(Table 6). 그 결과, 회수율 은 아목시실린이 소고기에서 $59.7 \pm 5.5 \%$, 닭고기에서 $59.9 \pm 0.9 \%$, 넙치에서 $61.2 \pm 1.6 \%$, 우유에서 $78.0 \pm 8.1 \%$ 로 Ramseshwari 연구 ${ }^{18}$ 에서 보고된 바와 같이 비교적 낮 은 수준이었다. P. Anfossi ${ }^{15}$ 와 S. De Baere ${ }^{19}$ 의 연구에 의하면 아목시실린은 수용액 상에서 안정성이 떨어지 며 또한 아목시실린을 수용액상으로 투여할 때는 6 12시간 마다 새롭게 만들어야 한다고 보고하고 있

Table 5. LOD and LOQ for detection penicillins in milk

\begin{tabular}{lcccc}
\hline \hline \multicolumn{1}{c}{ Compounds } & $\begin{array}{c}\mathrm{LOD} \\
(\mathrm{mg} / \mathrm{kg})\end{array}$ & $\begin{array}{c}\mathrm{LOQ} \\
(\mathrm{mg} / \mathrm{kg})\end{array}$ & $\mathrm{R}^{2}$ & $\begin{array}{c}\mathrm{CV} \\
(\%)\end{array}$ \\
\hline Amoxicillin & 0.0006 & 0.002 & 0.9998 & 10.4 \\
Ampicillin & 0.0003 & 0.001 & 0.9996 & 7.3 \\
Benzylpenicillin & 0.0003 & 0.001 & 0.9997 & 5.2 \\
Cloxacillin & 0.0015 & 0.005 & 0.9998 & 6.0 \\
Dicloxacillin & 0.0003 & 0.001 & 0.9998 & 6.8 \\
Nafcillin & 0.0003 & 0.001 & 0.9980 & 4.2 \\
Oxacillin & 0.0003 & 0.001 & 0.9999 & 6.0 \\
\hline
\end{tabular}

Table 6. Recovery $(\%)$ of penicillins in Beef, chicken, fish and milk $(n=3)$

\begin{tabular}{lrrrr}
\hline \multicolumn{1}{c}{ Compounds } & \multicolumn{1}{c}{ Beef } & \multicolumn{1}{c}{ Chicken } & \multicolumn{1}{c}{ Fish } & \multicolumn{1}{c}{ Milk } \\
\hline Amoxicillin & $59.7 \pm 5.5$ & $59.9 \pm 0.9$ & $61.2 \pm 1.6$ & $78.0 \pm 8.1$ \\
Ampicillin & $112.8 \pm 3.5$ & $61.8 \pm 0.8$ & $90.9 \pm 4.9$ & $88.0 \pm 6.4$ \\
Benzylpenicillin & $92.0 \pm 5.9$ & $102.6 \pm 2.7$ & $93.6 \pm 4.9$ & $106.3 \pm 5.5$ \\
Cloxacillin & $86.9 \pm 5.5$ & $84.8 \pm 2.2$ & $85.5 \pm 3.5$ & $90.6 \pm 5.4$ \\
Dicloxacillin & $79.6 \pm 4.4$ & $76.3 \pm 2.4$ & $81.3 \pm 1.4$ & $81.7 \pm 5.5$ \\
Nafcillin & $81.2 \pm 4.8$ & $76.0 \pm 2.5$ & $103.2 \pm 2.5$ & $89.4 \pm 3.8$ \\
Oxacillin & $89.4 \pm 6.3$ & $87.1 \pm 3.1$ & $89.6 \pm 3.5$ & $89.7 \pm 5.4$ \\
\hline
\end{tabular}


Table 7. The number of samples purchased in each district

\begin{tabular}{lcccccccc}
\hline \hline Sample & Seoul & Gwangju & Daegu & Daejeon & Busan & Ulsan & Incheon & Total \\
\hline Beef & 12 & 2 & 2 & 2 & 4 & 3 & 2 & 27 \\
Pork & 11 & 2 & 2 & 2 & 3 & 2 & 2 & 24 \\
Chicken & 12 & 2 & 3 & 2 & 4 & 2 & 2 & 27 \\
Flatfish & 7 & 2 & 2 & 2 & 2 & 2 & 2 & 19 \\
Rockfish & 9 & 1 & 2 & 2 & 3 & 2 & 2 & 21 \\
Eel & 12 & 2 & 2 & 1 & 3 & 2 & 2 & 24 \\
Shrimp & 12 & 2 & 3 & 2 & 3 & 2 & 2 & 26 \\
Milk & 13 & 2 & 2 & 3 & 5 & 2 & 2 & 29 \\
Egg & 13 & 2 & 3 & 2 & 3 & 3 & 2 & 28 \\
\hline Total & 101 & 17 & 21 & 18 & 30 & 20 & 18 & 225 \\
\hline
\end{tabular}

다. Chuangji $\mathrm{Liu}^{20}$ 의 연구에 의하면 아목시실린의 높은 극성으로 인해 회수율과 재현성이 떨어진다고 보고하 고 있다. 암피실린은 소고기, 닭고기, 넙치, 우유에서 각각 $112.8 \pm 3.5 \%, 61.8 \pm 0.8 \%, 90.9 \pm 4.9 \%, 88.0 \pm 6.4 \%$ 이 었으며, 벤질페니실린은 $92.0 \pm 5.9 \%, \quad 102.6 \pm 2.7 \%$, $93.6 \pm 4.9 \%, \quad 106.3 \pm 5.5 \%$, 클록사실린은 $86.9 \pm 5.5 \%$, $84.8 \pm 2.2 \%, 85.5 \pm 3.5 \%, 90.6 \pm 5.4 \%$, 디클록사실린은 $79.6 \pm 4.4 \%, 76.3 \pm 2.4 \%, 81.3 \pm 1.4 \%, 81.7 \pm 5.5 \%$, 나프실 린은 $81.2 \pm 4.8 \%, 76.0 \pm 2.5 \%, 103.2 \pm 2.5 \%, 89.4 \pm 3.8 \%$, 옥 사실린은 $89.4 \pm 6.3 \%, 87.1 \pm 3.1 \%, 89.6 \pm 3.5 \%, 89.7 \pm 5.4 \%$ 으로 양호한 결과를 얻었다.

\section{2. 페니실린계 동물용의약품 모니터링 결과}

국내 유통 중인 축 - 수산물 225건을 수거하여 페니 실린계 동물용의약품 7종에 대한 잔류량을 조사한 결 과 벤질페니실린이 축산물에서 12 건, 수산물에서 7 건 으로 총 19건이 검출되었고 나머지 6개 항목인 아목 시실린, 암피실린, 클록사실린, 디클록사실린, 나프실 린, 옥사실린은 검출되지 않았다. 정량은 Table 1의 조 건으로 표준용액과 시험용액을 각각 질량분석기에 주 입하여 Table 1의 특이이온을 확인한 후 크로마토그램 으로부터 얻은 피크의 머무름 시간을 비교하고 각각 의 정량이온에 대한 면적을 구하고 검량선을 작성하 여 시험용액 중 해당물질의 함량을 구하였다. 벤질페 니실린이 검출된 축산물은 우유와 알을 제외한 소고 기, 돼지고기, 닭고기이었으며 검출건수는 소고기에서 7건, 돼지고기에서 2건, 닭고기에서 3건이었다. 검출 수준은 0.001 0.009 mg/kg으로 잔류허용기준(MRL)인 $0.05 \mathrm{mg} / \mathrm{kg}$ 이하로 검출되었다. 수산물은 넙치에서 2 건, 조피볼락에서 1 건, 장어에서 2 건, 새우에서 2건으 로 총 7건이 검출되었으며 검출된 7건 모두 잔류허용 기준인 $0.03 \mathrm{mg} / \mathrm{kg}^{12}$ 이하로 검출되었다. 각 검체별
Table 8. The number of detected sample and the residue level on penicillins

\begin{tabular}{lccc}
\hline \hline \multicolumn{1}{c}{ Analyte } & $\begin{array}{c}\text { No. of } \\
\text { samples }\end{array}$ & $\begin{array}{c}\text { No. of detected } \\
\text { samples }\end{array}$ & $\begin{array}{c}\text { Residue level } \\
(\mathrm{mg} / \mathrm{kg})\end{array}$ \\
\hline Amoxicillin & 225 & 0 & N.D.* \\
Ampicillin & 225 & 0 & N.D. \\
Benzylpenicillin & 225 & 19 & $0.001 \sim 0.009$ \\
Cloxacillin & 225 & 0 & N.D. \\
Dicloxacillin & 225 & 0 & N.D. \\
Nafcillin & 225 & 0 & N.D. \\
Oxacillin & 225 & 0 & N.D. \\
\hline
\end{tabular}

*N.D.: Not detected

Table 9. The number of detected sample in total samples and the residue level of benzylpenicillin

\begin{tabular}{lcrcc}
\hline \hline Sample & $\begin{array}{c}\text { No. of } \\
\text { detected/ } \\
\text { Total samples }\end{array}$ & $\begin{array}{c}\text { Detection } \\
\text { rate } \\
(\%)\end{array}$ & $\begin{array}{c}\text { MRL } \\
(\mathrm{mg} / \mathrm{kg})\end{array}$ & $\begin{array}{c}\text { Residue } \\
\text { level } \\
(\mathrm{mg} / \mathrm{kg})\end{array}$ \\
\hline Beef & $7 / 27$ & 25.9 & 0.05 & $0.001 \sim 0.007$ \\
Pork & $2 / 24$ & 8.3 & 0.05 & $0.003,0.005$ \\
Chicken & $3 / 27$ & 11.1 & 0.05 & $0.005 \sim 0.009$ \\
Flatfish & $2 / 20$ & 10 & 0.03 & $0.004,0.005$ \\
Rockfish & $1 / 21$ & 4.8 & 0.03 & 0.001 \\
Eel & $2 / 24$ & 8.3 & 0.03 & $0.003(2)$ \\
Shrimp & $2 / 26$ & 7.7 & 0.03 & $0.003,0.006$ \\
Milk & $0 / 29$ & 0 & 0.004 & N.D.* \\
Egg & $0 / 28$ & 0 & 0.004 & N.D. \\
\hline Total & $19 / 225$ & 8.4 & - & - \\
\hline
\end{tabular}

*N.D.: Not detected

수거건수 및 검출건수는 Table 7와 Table 8에 나타내 었고, 검출수준과 검출률(\%)은 Table 9에 나타내었다. 이전에 수행된 페니실린계 동물용의약품 실태조사 결 과를 살펴보면 주로 아목시실린과 암피실린에 대한 

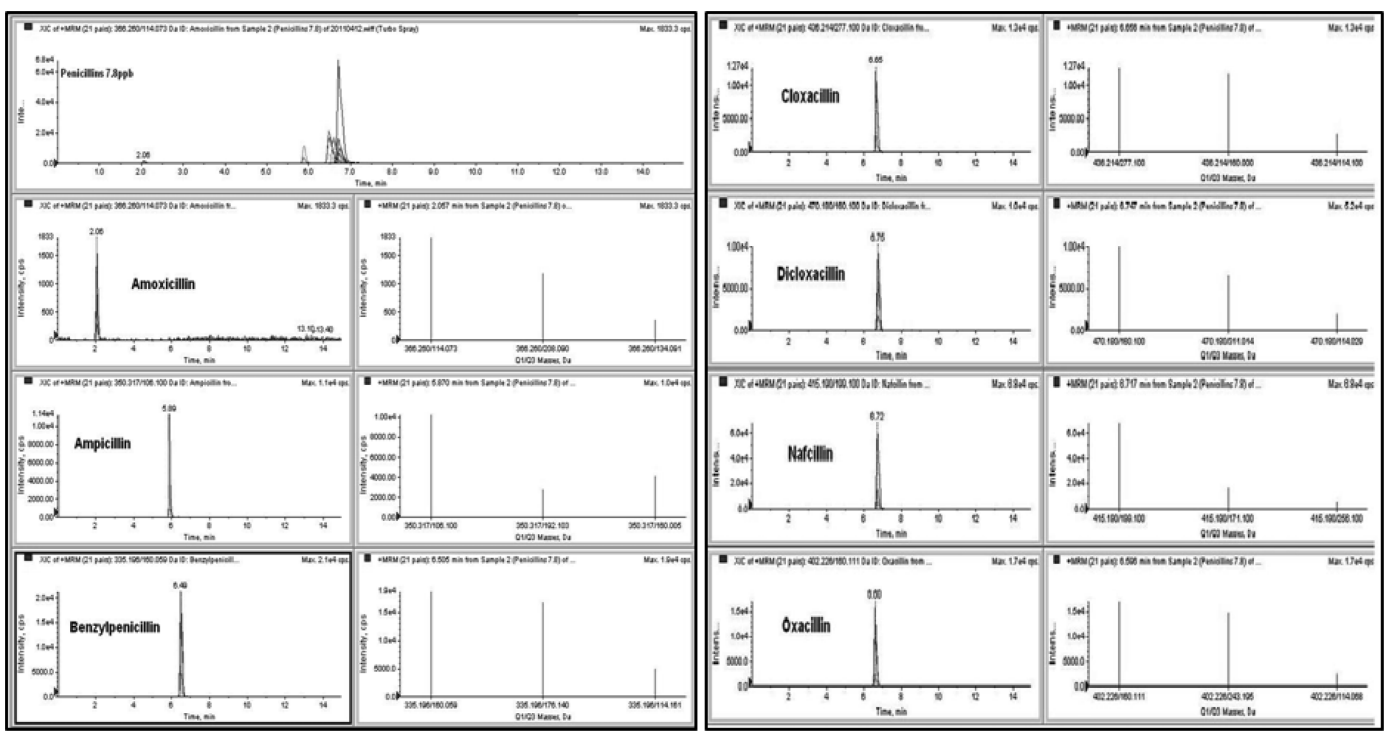

Fig. 4. Chromatogram of penicillins standards using HPLC-ESI-MS/MS.

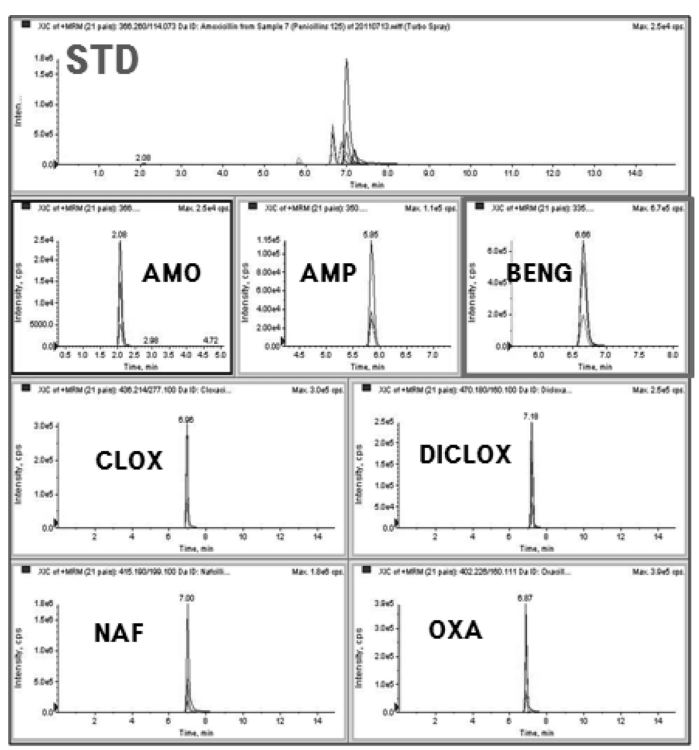

(a)

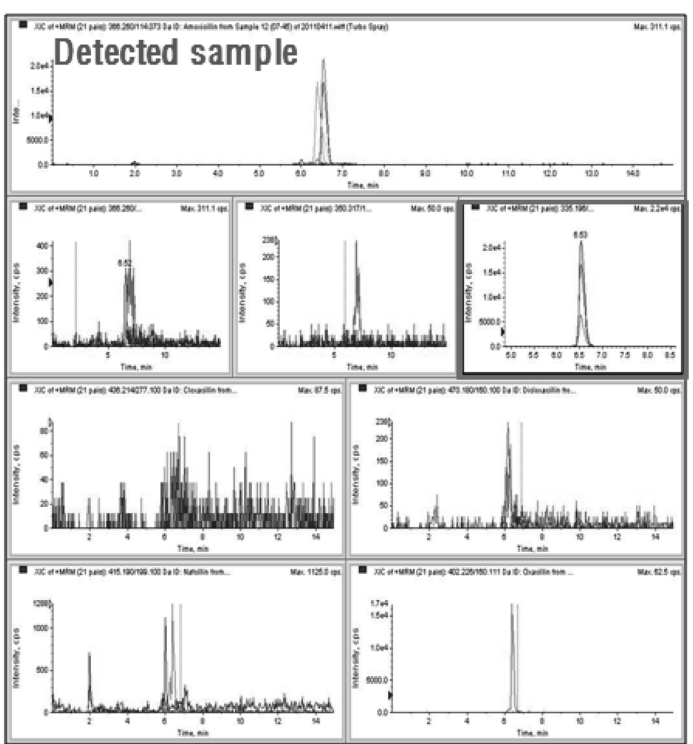

(b)

Fig. 5. Chromatogram of (a) penicillins standard and (b) benzylpenicillin detected sample.

모니터링이었으며 벤질페니실린을 비롯한 그 외 페니 실린계 동물용의약품에 대한 모니터링은 수행되지 않 았다. 2009년에 수행된 국내 유통 식품의 잔류동물용 의약품 모니터링 결과1를 보면, 축수산물 175 건의 시료 중 넙치 4건(2.3\%)에서 아목시실린이 $0.040 .33 \mathrm{mg} / \mathrm{kg}$ 농도로 검출된 사례가 있었으며, 또한 2006년에 수행된 식품 중 아목시실린, 암피실린, 옥소린산 및 플루메퀸
의 분석 ${ }^{21}$ 에서 넙치를 대상으로 모니터링 한 결과, 78 건의 시료 중 9건(11.5\%)에서 아목시실린이 0.009 0.078 $\mathrm{mg} / \mathrm{kg}$ 범위로 검출된 사례가 있었다. 본 연구에서의 모 니터링 결과, 페니실린계 동물용의약품의 잔류실태는 비교적 안전한 것으로 나타났으며 잔류노출 가능성이 있는 벤질페니실린에 대해서는 보다 지속적이고 제도 적인 관리가 요구되는 것으로 사료된다. 


\section{4. 결 론}

본 연구에서 국내 유통 중인 축 - 수산물 225건을 수 거하여 페니실린계 동물용의약품인 아목시실린, 암피 실린, 벤질페니실린, 클록사실린, 디클록사실린, 나프 실린, 옥사실린 등 7종에 대한 잔류량을 조사한 결과 벤질페니실린이 축산물에서 12 건, 수산물에서 7 건으 로 총 19건이 검출되었고 나머지 6개 항목인 아목시 실린, 암피실린, 클록사실린, 디클록사실린, 나프실린, 옥사실린은 검출되지 않았다. 벤질페니실린이 검출된 축산물은 우유와 알을 제외한 소고기, 돼지고기, 닭고 기에서 12 건 이었으며 검출 수준은 $0.001 \sim 0.009 \mathrm{mg} /$ $\mathrm{kg}$ 으로 잔류허용기준(MRL)인 $0.05 \mathrm{mg} / \mathrm{kg}$ 이하로 검 출되었다. 수산물은 검출된 7건 모두 잔류허용기준인 $0.03 \mathrm{mg} / \mathrm{kg}$ 이하로 검출되었다.

\section{감사의 글}

본 연구는 2011년도 식품의약품안전청 연구개발과 제의 연구개발비 지원(11161식품안035)에 의해 수행 되었으며, 이에 감사드립니다.

\section{참고문헌}

1. H. Y. Kim and E. C. Seo, Korean J. Food Sci. Technol., 42(6), 653-663 (2010).

2. S. K. Lim, The Annual Report of KFDA, Korea, 11, 644-645 (2007).

3. A. A. M. Stolker and U. A. T. Brinkman, J. Chromatogr. A, 1067, 15-53 (2005).

4. G. J. Heo, K. S. Shin and M. H. Lee, Kor. J. Food Hygiene., 7, S7-S19 (1992).

5. S. C. Jung, The Annual Report of KFDA, Korea, 7, 1113-1114 (2003).

6. T. S. Lee, The Annual Report of KFDA, Korea, 7, 1115-1116 (2003).

7. S. C. Jung, The Annual Report of KFDA, Korea, 8-2,
2223-2224 (2004).

8. T. S. Lee, The Annual Report of KFDA, Korea, 8-2, 2225-2226 (2004).

9. S. C. Jung, The Annual Report of KFDA, Korea, 9, 420-421 (2005).

10. T. S. Lee, The Annual Report of KFDA, Korea, 9, 422423 (2005).

11. S. O. Song, M. H. Cho, K. S. Shin, M. H. Lee, P. D. Ryu, B. G. Jeong, S. W. Lee and H. G. Lee, Kor. J. Vet. Publ. Hlth., 18, 343-352 (1994).

12. KFDA. Korea Food Code. Korea Food and Drug Administration, Seoul, Korea.(2011)

13. Y. H. Jung and K. G. Lee, The Annual Report of KFDA, Korea, 9, 414-415 (2005).

14. H. C. Shin and K. Park, The Annual Report of KFDA, Korea, 10, 530-531 (2006).

15. P. Anfossi, A. Zaghini, G. Grassigli, S. Mwnotta and G. Fedrizzi, J. Vet. Pharmacol. Ther, 25, 329 (2002).

16. J.-A. Do and C. H. Kwon, The Annual Report of KFDA, 14, 113-114 (2010).

17. ACS Committee on Environmental Improvement. Guidelines for data acquisition and data quality evaluation in enviromental chemistry. Anal. Chem., 52, 2242-2249 (1980).

18. Multi-Class, Multi Residue Method for Determination of Penicillins, Cephalosporins and Quinolines in Cow Milk and Validation in Accordance with Commission Decision 2002/657/EC. submitted by Rameshwari Amatya February, 2010

19. S. De Baere and Patrick De Backer, Anal Chim Acta, 586, 319-325 (2007).

20. Chuangji Liu, Hai Wang, Yanbin Jiang and Zhenxia Du, J. Chromatogr B., 879, 533-540 (2011).

21. H. Y. Kim, H. J. Choi, Y. H. Kim, S. H. Choi, S. Y. Cheong, H. J. Lee, J. I. Kim, G. S. Cjoi and J. Choi, Korean J. Food Sci. Technol., 41, 490-497 (2009). 